\title{
The effect of native propolis on serum biochemical parameters in weaned piglets
}

\author{
Ivana Stolić1, Maja Popovićc ${ }^{2 *}$, Gordan Mršicín, Ksenija Vlahović \\ and Danijel Špoljarićc
}

${ }^{I}$ Department of Chemistry and Biochemistry, Faculty of Veterinary Medicine, University of Zagreb, Zagreb, Croatia

${ }^{2}$ Department of Veterinary Biology, Faculty of Veterinary Medicine, University of Zagreb, Zagreb, Croatia

${ }^{3}$ The Ministry of the Interior of the Republic of Croatia, Zagreb, Croatia

STOLIĆ, I., M. POPOVIĆ, G. MRŠIĆ, K. VLAHOVIĆ, D. ŠPOLJARIĆ: The effect of native propolis on serum biochemical parameters in weaned piglets. Vet. arhiv 89, 201-210, 2019.

\section{ABSTRACT}

The aim of this study was to determine the influence of native propolis on the growth performance of weaned piglets by monitoring changes to the selected biochemical parameters (total proteins, albumins, ALP, AST, ALT, GGT, GLU, UREA, CHOL and TRIG). Sixty piglets were divided into 2 groups. Piglets in the control group (CON-30) were fed with a standard feed mix (SFM) while the SFM of the piglets in experimental (EXP-30) group was daily enriched with propolis in a dose of $1 \mathrm{~g} / \mathrm{kg}$ SFM. Feed intake, mortality and serum biochemical parameters were monitored regularly. In the EXP-30 group the levels of ALP, GGT, UREA, CHOL and TRIG increased while the concentration of albumins decreased compared to the CON-30 group. This study showed that propolis-enriched food positively influenced overall health, which may in the long-term provide faster growth of healthier and heavier animals.

Key words: piglets; native propolis; growth; isoflavonoids

\section{Introduction}

All agricultural industries, including the pig industry, have changed considerably over the last few decades. The pig industry is a business and as such it has to become more economically sustainable, socially responsible, environmentally aware and ethically conscious (HUYNH et al., 2007). To remain competitive and profitable on the market, producers use automation, and they take care of their animals' nutrition, health and reproduction. To prevent mortality, diseases and low yields, they use antibiotic

\footnotetext{
${ }^{*}$ Corresponding author:

Prof. dr. sc. Maja Popović, PhD, Department of Veterinary Biology, Faculty of Veterinary Medicine, University of Zagreb, Heinzelova 55, 10000 Zagreb, Croatia, Phone: +385 912390 140; Fax: +385 12441 390; E-mail: mpopovic22@gmail.com
} 
growth promoters. According to LANDERS et al. (2012) antibiotic growth promoters are compounds used to "help growing animals digest their food more efficiently, get maximum benefit from it and allow them to develop into strong and healthy individuals". However, the unreasonable use of antibiotic growth promoters has given rise to the fear of the development of resistant bacteria and their transfer from animals to humans (CHENG et al., 2014). Therefore, over the last few decades new growth promoters have been introduced. They are antibacterial vaccines, immunomodulatory agents, bacteriophages and their lysines, antimicrobial peptides (AMPs), pro-, pre-, and synbiotics, plant extracts, inhibitors for bacterial quorum sensing (QS), biofilm, and virulence and feed enzymes (MILLET and MAERTENS, 2011).

This study is a continuation of our previous studies dealing with natural supplements as an alternative to antibiotics in the production of wholesome meat for human consumption (ŠPOLJARIĆ et al., 2013). In this study, we explored the influence of propolis, a well known immunomodulator (ORŠOLIĆ et al., 2002), on the growth and overall health of weaned piglets, to see if it can improve the production performance.

Propolis is a resinous mixture that bees collect from plants and trees or other plant sources. Raw propolis is typically composed of $50 \%$ plant resins, $30 \%$ wax, $10 \%$ essential and aromatic oils, $5 \%$ pollen and $5 \%$ other organic substances (HUANG et al., 2014). According to the chemical structure, most of the compounds belong to the following classes: flavonoids, phenylpropanoids, terpenoids, stilbenes, lignans, coumarins and their prenylated derivatives. The antioxidant, antimutagenic, immunomodulatory and cytostatic effects of propolis are associated with its flavonoid, phenolic acid and terpenoid content (FARNESI et al., 2009; ARSLAN and SEVEN, 2017). Flavonoids, as the major constituents of propolis, contribute greatly to its pharmacological activities. Flavonoids, together with cinnamic acid derivatives, such as: acacetin, quercetin, naringenin, caffeic acid phenyl ester (CAPE) and caffeic acid (CA), are responsible for its anti-inflammatory activity, while its antimicrobial activity is primarily associated with the presence of bioactive phytochemicals, such as: phenolic acid, cinnamic acid, pinocembrin, galangin, pinobanksin and their structural analogues (KROL et al., 1993; KOO et al., 2000; ALMEIDA and MENEZES, 2002; STEPANOVIĆ et al., 2003; FARNESI et al., 2009; GUZMAN, 2014).

This study aimed to determine the effects of propolis on the growth performance, mortality and overall health of weaned piglets, by monitoring changes to the selected serum biochemical parameters (glucose, albumin, total protein, cholesterol, triglycerides, urea, alkaline phosphatase (ALP), aspartate aminotransferase (AST), alanine aminotransferase (ALT), Gamma-Glutamyl Transferase (GGT) in the first few week after weaning.

\section{Materials and methods}

Propolis. Native propolis was used from a commercial beekeeping family farm in eastern Croatia (Ivanić Grad). Freshly picked, native propolis was first cooled to -20 
${ }^{\circ} \mathrm{C}$ and was then ground into pieces. A raw sample was prepared for testing according the procedure by ŠPOLJARIĆ et al. (2013). The presence of heavy metals in the native propolis was analysed using a SEM electronic microscope, Philips XL 30, with an EDX detector, using the Genesis version 6.02 program package (the Ivan Vučetić Centre for Forensic Investigations, Research and Expertise, Zagreb, Croatia).

Piglets. The experiment was conducted on a commercial pig farm (Polonje, Sveti Ivan Zelina, Croatia). Sixty piglets were used in the experiment (cross-breeds of Swedish Landrace and Yorkshire), females and castrates, a uniform weight of about $7 \mathrm{~kg}$, aged 28 days. The piglets were weaned and divided into two groups, CON-30 (30 piglets) and EXP-30 (30 piglets) at 26 days of life. The experiment began with the weaned piglets after two days of adjustment to new conditions (28 days of life).

Study design and procedures. The piglets were divided into two groups (control and experimental) with 30 piglets in each group, and kept in individual boxes within the same barn. The experiment lasted 28 days (up to 56 days of life). The piglets in the control group were fed with a standard feed mix (the grain-soybean meal-based diet recipe, according to farm owner, was composed of: crude proteins $20.0 \%$, crude fat $50.0 \%$, crude fibre $3.7 \%$, calcium $0,6 \%$, phosphorus $0.51 \%$, sodium $0.29 \%$, lysine $1.64 \%$, methionine and cysteine $0.83 \%$; ME/MJ 14.05). The piglets in experimental groups were fed daily with standard feed mix enriched with $0.1 \%$ (1g per $1 \mathrm{~kg}$ food) of propolis. During the experiment food and water were available ad libitum. All the procedures used in this research were in compliance with the European guidelines for the care and use of animals in research (Directive 2010/63/EC) and had approval from the Ethics Committee for Animal Experimentation, Faculty of Veterinary Medicine, University of Zagreb, Croatia (records No.: 640-01/13-17/36; file No.: 251/61-01/139-13-2).

Monitoring of health indicators. The piglets were weighed at weekly intervals during the experiment, and changes in their body weight were recorded. Body weight gain was calculated as the initial and final weights of the different periods. The pigs were monitored daily for diarrhoea and other clinical signs of health disorders, such as anorexia and weight loss. The intensity of diarrhoea was determined by the faecal consistency scoring method, as described previously by VALPOTIĆ et al. (2016).

Blood sampling and analysis. Blood samples for biochemistry analysis were collected on the $0,14^{\text {th }}, 21^{\text {st }}$, and $28^{\text {th }}$ days of the experiment. Blood samples $(3 \mathrm{~mL})$ were taken from the cranial vein into glass tubes for serum biochemistry (Venosafe, Terumo, EU)containing gel and ClotAct. (3.5 mL). Blood was collected from seven marked (by numbers 1-7) piglets in each group.

Serum biochemical parameters. Serum proteins, albumins, liver enzymes (alkaline phosphatase (ALP), aspartate aminotransferase (AST), alanine aminotransferase (ALT), Gamma-Glutamyl Transferase (GGT), glucose, urea, cholesterol and triglycerides were 
determined by the standard methods using an Olympus AU 600 analyser (Olympus Diagnostic, Hamburg, Germany). The obtained results were evaluated in relation to the reference values for domestic pigs (JACKSON and COCKCROFT, 2007).

Statistical analysis. The software packages JMP 7.0 (Business unit if SAS, SAS inc.) and Orgin 7.0 were used for statistical analysis. The normality of data distribution was tested using the Kolmogorov-Smirnovim test. The significance of differences between the experimental and the control group was determined by the Student T-test. Analysis of variance was used for determining the significance of differences between individual weighing within the groups (ANOVA Repeated Measures, with the Unequal $n$ HSD test for post-hoc analysis). The level of statistical significance was $p<0.05$. All data are presented as mean \pm standard error of the mean (SEM).

\section{Results}

Exhaust gases from vehicles and industry, along with other pollutants are the main sources of heavy metals which are the most common toxic contaminants of living organisms. Taking into consideration the possible contamination of propolis with toxic metals that may affect the normal development of the piglets, heavy metal analyses were conducted. Heavy metals analysis by SEM electron microscope did not reveal any metals in the propolis sample (Fig. 1).

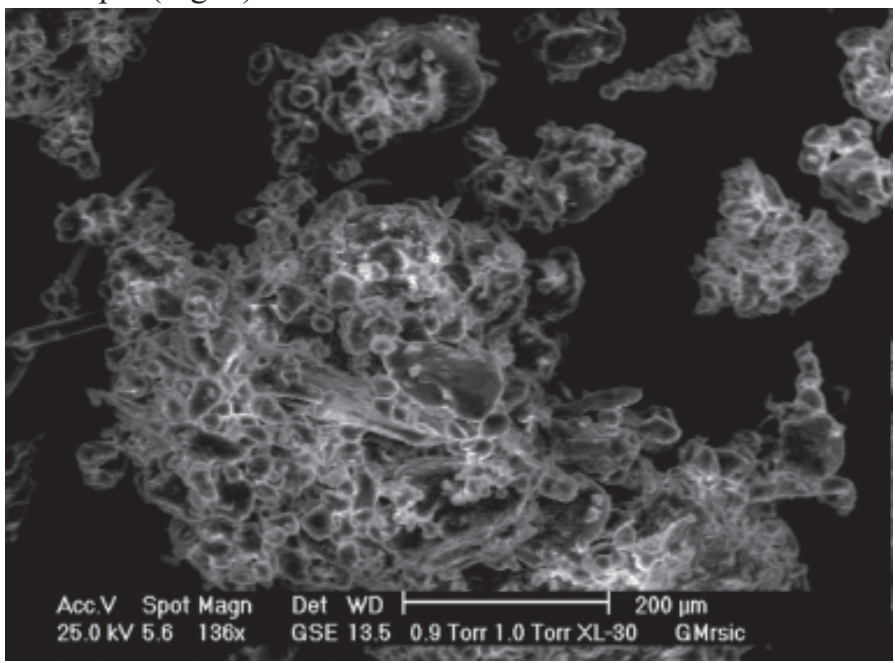

Fig. 1. Ultrastructure of natural propolis visualized by a SEM electronic microscope Philips XL 30 with an EDX detector using the Genesis program package version 6.02. (Source: The Ivan

Vučetić Centre for Forensic Investigations, Research and Expertise, Zagreb, Croatia). 
The results of the present study indicate that propolis supplementation does not affect body weight. At the beginning of the experiment the average mass of the piglets in the CON30 group was $6.8 \pm 0.2 \mathrm{~kg}$ and in the EXP-30 group it was $6.6 \pm 0.2 \mathrm{~kg}$. At the end of the experiment ( $28^{\text {th }}$ day) piglets in the CON-30 group had an average mass of $10.9 \pm 0.4 \mathrm{~kg}$, and in the EXP-30 group, $10.6 \pm 0.4 \mathrm{~kg}$. However, propolis did affect the number of cases of diarrhoea. Piglets in the control group had diarrhoea more frequently (6/30) than the piglets in the experimental group (2/30). In both groups piglets with profuse diarrhoea died.

The values of the biochemical parameters for both groups are summarized in Table 1. In both groups the most significant changes occurred within the first two weeks of the experiment, after which the values of most parameters did not change significantly. At the end of the experiment, in both groups the concentrations of total proteins (TP) and UREA, and the level of hepatic enzymes (ALP, AST, ALT and GGT) had increased, while the concentration of abumins (ALB) had decreased. Concentrations of CHOL and TRIG in the CON-30 group decreased while in the EXP-30 group they increased (Table 1).

Table 1. The values of biochemical parameters in the peripheral blood of weaned pigs fed with a diet supplemented with natural propolis on days $0,14,21$ and 28 of the experiment

\begin{tabular}{|c|c|c|c|c|c|}
\hline Groups & Variable & 0 day & 14 day & 21 day & 28 day \\
\hline \multirow{10}{*}{$\mathrm{CON}-30^{\mathrm{a}}$} & T.P. ${ }^{\mathrm{b}}(\mathrm{g} / \mathrm{L})$ & $45.18 \pm 1.19$ & $46.96 \pm 2.22$ & $43.89 \pm 2.34$ & $50.41 \pm 2.00$ \\
\hline & $\operatorname{ALB}(\mathrm{g} / \mathrm{L})$ & $29.61 \pm 0.59$ & $27.30 \pm 1.15$ & $22.31 \pm 1.35$ & $22.71 \pm 0.69$ \\
\hline & ALP (U/L) & $200.29 \pm 3.85$ & $448.71 \pm 58.83$ & $349.43 \pm 45.73$ & $259.43 \pm 37.62$ \\
\hline & AST (U/L) & $31.41 \pm 3.35$ & $50.81 \pm 4.33$ & $52.12 \pm 5.87$ & $76.4 \pm 11.15^{*}$ \\
\hline & CHOL $(\mathrm{mmol} / \mathrm{L})$ & $3.25 \pm 0.32$ & $1.73 \pm 0.21$ & $1.44 \pm 0.11$ & $1.97 \pm 0.19$ \\
\hline & TRIG (mmol/L) & $0.94 \pm 0.11$ & $0.49 \pm 0.03$ & $0.57 \pm 0.04$ & $0.60 \pm 0.06$ \\
\hline & ALT (U/L) & $37.43 \pm 3.66$ & $74.14 \pm 7.01$ & $113.47 \pm 14.04$ & $100.51 \pm 15.51$ \\
\hline & GGT (U/L) & $22.11 \pm 3.94$ & $32.21 \pm 4.84$ & $31.81 \pm 4.79$ & $32.41 \pm 5.54$ \\
\hline & GLUK $(\mu \mathrm{mol} / \mathrm{L})$ & $6.51 \pm 0.43$ & $5.74 \pm 0.57$ & $5.07 \pm 0.21$ & $5.72 \pm 0.22$ \\
\hline & UREA $(\mathrm{mmol} / \mathrm{L})$ & $4.22 \pm 0.30$ & $3.32 \pm 0.31$ & $5.19 \pm 0.37$ & $5.22 \pm 0.45$ \\
\hline \multirow{10}{*}{ EXP-30 } & T.P. $(\mathrm{g} / \mathrm{L})$ & $40.14 \pm 0.80$ & $46.12 \pm 1.01$ & $37.53 \pm 0.73 *$ & $45.60 \pm 0.64 *$ \\
\hline & ALB (g/L) & $27.0 \pm 1.09$ & $23.91 \pm 0.96^{*}$ & $17.24 \pm 0.54 *$ & $18.15 \pm 0.66^{*}$ \\
\hline & ALP (U/L) & $178.14 \pm 24.24$ & $315.00 \pm 17.79 *$ & $248.14 \pm 40.48$ & $377.00 \pm 57.21$ \\
\hline & AST (U/L) & $24.71 \pm 2.31 *$ & $37.40 \pm 3.17$ & $43.11 \pm 5.36$ & $54.04 \pm 3.99$ \\
\hline & $\mathrm{CHOL}(\mathrm{mmol} / \mathrm{L})$ & $2.35 \pm 0.14^{*}$ & $2.16 \pm 0.09$ & $1.99 \pm 0.15^{*}$ & $2.78 \pm 0.18^{*}$ \\
\hline & TRIG (mmol/L) & $0.49 \pm 0.04$ & $0.62 \pm 0.02$ & $0.58 \pm 0.11$ & $0.86 \pm 0.09 *$ \\
\hline & ALT (U/L) & $37.79 \pm 3.67$ & $70.87 \pm 8.09$ & $76.40 \pm 13.85$ & $102.46 \pm 17.25$ \\
\hline & GGT (U/L) & $18.08 \pm 1.66$ & $29.19 \pm 2.51$ & $27.84 \pm 2.06$ & $38.14 \pm 1.77$ \\
\hline & GLUK $(\mu \mathrm{mol} / \mathrm{L})$ & $5.45 \pm 0.19^{*}$ & $5.34 \pm 0.15$ & $4.93 \pm 0.29$ & $5.33 \pm 0.25$ \\
\hline & UREA $(\mathrm{mmol} / \mathrm{L})$ & $3.37 \pm 0.19$ & $5.33 \pm 0.46$ & $5.86 \pm 0.35$ & $5.81 \pm 0.44^{*}$ \\
\hline
\end{tabular}

${ }^{a}$ control group; $\underline{b}$ experimental group; *statistical significance $\mathrm{P} \leq 0.05$ compared to CON-30 group 
I. Stolić et al.: Effect of native propolis on biochemical parameters in weaned piglets

\section{Discussion}

It is well-known that a stronger and more permanent immune system increases growth, food absorption, and reproductive potential (POTOČNJAK et al., 2012). Our present results indicate that the addition of native propolis did not affect the piglets' mass. Piglets in both groups gained approximately the same weight after 4 weeks of the experiment. Of all diseases in the post-weaning period diarrhoea is the most important. It is responsible for high morbidity and mortality, and as such causes enormous economic loss. This experiment showed that the addition of propolis reduced diarrhoea. The EXP30 group had three times less diarrhoea than the CON-30 group. In both groups piglets with profuse diarrhoea died.

Our present results indicate that the concentrations of total proteins (TP) and glucose (GLU) were not influenced by propolis treatment (Table 1). The concentration of proteins in both groups increased up to $15 \%$, while the concentration of glucose was imperceptibly changed. The activity of the enzymes ALP, AST, ALT and GGT indicate the state of the tissues and organs for which these enzymes are specific, while levels higher than the standard indicate damage to muscle tissue, liver function and bile acid (BOBIĆ et al., 2009). The activities of the serum marker enzymes (AST, ALT and ALP) were found to be elevated but within physiological values in both groups (Table 1). Propolis did not affect the levels of AST and ALT enzymes, in both groups an increase between $50-70 \%$ was observed. However, propolis affected the concentrations of albumins and urea, as well as the levels of GGT and ALP enzymes. At the end of experiment it was observed that the addition of propolis on average reduced the concentration of albumins in the EXP-30 group by $30 \%$, and elevated the levels of ALP, GGT and urea by an average of $60-70 \%$ compared to the control group. Elevated activity of hepatic enzymes in plasma occurs as a result of the hepatic induction of the enzyme (PURKINS et al., 2003). The ingredients of propolis that are responsible for elevated level of the ALP enzyme are isoflavonoids, such as daidzein and genistein. Isoflavonoids are natural endocrine active compounds generally considered to promote health, and prevent or slow the onset of certain chronic diseases, such as osteoporosis (NISCHIDE et al., 2015; ZHENG et al., 2017). A number of studies have reported that soy isoflavonoid dose-dependently inhibits bone loss in both female and male osteoporotic animal models (REINWALD and WEAVER, 2006). Alkaline phosphatase (ALP) is an enzyme present in a number of tissues, including liver, bone, intestines, and placenta. Level of this enzyme are elevated in disorders of the skeletal system, such as osteoblast hyperactivity and bone remodelling, hyperparathyroidism, rickets, malignant tumours, growth and so on (ROSOL and CAPEN, 1999). In this study, the higher level of ATP was the result of the skeletal disorder associated with the growth of young animals. The amount of cholesterol in pig tissues generally increases over time (WERDI PRATIWI et al., 2006). From literature is known that the total cholesterol 
concentration in pigs is related to LDL and HDL cholesterol concentrations (RAUW et al., 2007). In addition, a positively phenotypically correlation was observed between total cholesterol plasma and triglyceride plasma levels. The results of the present study indicate that cholesterol and triglyceride plasma levels measured in both groups were very highly positively related. At the end of the experiment, concentrations of cholesterol and triglycerides in the CON-30 group decreased by approximately $40 \%$ while in EXP-30 group their values increased, cholesterol up to $16 \%$ and triglycerides up to $43 \%$. The only significant difference was the increase of more than $40 \%$ in triglycerides.

\section{Conclusion}

The health-promoting properties of propolis and its physiological effects depend on a range of factors, including chemical composition, relating to the concentration, absorption and metabolic transformation of individual compounds as well as the administered dose. In the blood serum of piglets fattened with the propolis supplement a significantly higher level was found of cholesterol (by 16\%), triglycerides (by $40 \%$ ), urea, gammaglutamyltransferase and asparagine aminotransferase (by approximately 60-70\%) while the concentration of albumins was significantly reduced (by $30 \%$ ) compared to the CON30 group. Other test parameters were not affected by propolis addition. The changes observed in both groups were within the physiological range of indicators of growth and development of young animals. The more pronounced changes in the experimental group may be attributed to the immunomodulatory activity of propolis. Piglets in the experimental group had lower incidence of diarrhoea, due to the presence of antimicrobial compounds such as cinnamic acid and their derivatives. The significant increase in the level of alanine aminotransferase enzymes in their blood indicates faster growth, from which the influence of propolis is noticeable, that is its ingredients such as isoflavonoids, on the animals' development. This study showed that propolis-enriched food had a positive influence on overall health, which can in the long-term lead to faster growth of heavier and healthier animals.

\section{Acknowledgements}

The study was conducted within the framework of VIP project (2012-11-17).

\section{References}

ALMEIDA, E. C. D., H. MENEZES (2002): Anti-inflammatory activity of propolis extracts: a review. J. Venom. Anim. Toxins 8, 191-212.

DOI: $10.1590 / \mathrm{S} 0104-79302002000200002$ 
I. Stolić et al.: Effect of native propolis on biochemical parameters in weaned piglets

ARSLAN, A. S., P. T. SEVEN (2017): The effects of propolis on serum malondialdehyde, fatty acids and some blood parameters in Japanese quail (Coturnix coturnix japonica) under high stocking density. J. Appl. Anim. Res. 45, 417-422.

DOI: 10.1080/09712119.2016.1206901

BOBIĆ, T., T. ŠPERANDA, V. POZNIĆ, M. ĐIDARA, V. ŠERIĆ, M. DOMAČINOVIĆ, Z. ANTUNOVIĆ, N. KNEZOVIĆ, M. ŠPERANDA (2009): A higher dietary level of organic selenium in weaned piglets' diet. Krmiva 51, 153-159.

CHENG, G., S. HAO, X. WANG, M. DAI, L. HANG, Z. YUAN (2014): Antibiotic alternatives: the substitution of antibiotics in animal husbandry? Front Microbiol. 5: 1-15.

DOI: $10.3389 /$ fmicb.2014.00217

FARNESI, A. P., R. AQUINO-FERREIRA, D. DE JONG, J. K. BASTOS, A. E. E. SOARES (2009): Effects of stingless bee and honey bee propolis on four species of bacteria. Genet. Mol. Res. 8, 635-640.

DOI: $10.4238 /$ vol8-2kerr023

GUZMAN, J. D. (2014): Natural cinnamic acids, synthetic derivatives and hybrids with antimicrobial activity. Molecules 19, 19292-19349.

DOI: $10.3390 /$ molecules 191219292

HUANG, S., P. ZHANG, K. WANG, G. O. LI, F. L. HU (2014): Recent advances in the chemical composition of propolis. Molecules 19, 19610-19632.

DOI: $10.3390 /$ molecules 191219610

HUYNH, T. T. T., A. J. A. AARNINK, A. DRUCKER, M. W. A. VERSTEGEN (2007): Pig production in Cambodia, Laos, Philippines, and Vietnam: A review. AJARD 4, 69-90.

JACKSON, P. G. G., P. D. COCKCROFT (2007): Handbook of Pig Medicine. $2^{\text {nd }}$ ed. Saunders Elsevier, Edinburgh, London, New York.

KOO, H., B. P. F. A. GOMES, P. L. ROSALEN, G. M. B. AMBROSANO, Y. K. PARK, J. A. CURY (2000): In vitro antimicrobial activity of propolis and Arnica montana against oral pathogens. Arch. Oral Biol. 45, 141-148

DOI: 10.1016/S0003-9969(99)00117-X

KROL, W., S. SCHELlER, J. SHANI, G. PIETSZ, Z. CZUBA (1993): Synergistic effect of ethanolic extract of propolis and antibiotics on the growth of Staphylococcus aureus. Arzneimittelforschung. 43, 607-609.

LANDERS, T. F., B. COHEN, T. E. WITTUM, E. L. LARSON (2012): A review of antibiotic use in food animals: perspective, policy and potential. Public Health Rep. 127, 4-22.

DOI: $10.1177 / 003335491212700103$

MILLET, S., L. MAERTENS (2011): The European ban on antibiotic growth promoters in animal feed: from challenges to opportunities. Vet. J. 187, 143-144.

DOI: $10.1016 /$ j.tvj1.2010.05.001 
I. Stolić et al.: Effect of native propolis on biochemical parameters in weaned piglets

NISCHIDE, Y., Y. TOUSEN, M. TADAISHI, M. INADA, C. MIYAURA, M. C. KRUGER, Y. ISHIMI (2015): Combined effects of soy isoflavones and $\beta$-carotene on osteoblast differentiation. Int. J. Environ. Res. Public Health 12, 13750-13761.

DOI: $10.3390 /$ ijerph121113750

ORŠOLIĆ, N., A. H. KNEŽEVIĆ, I. BAŠIĆ (2002): Propolis as a new potential immunomodulator in mice: antimetastatic activity of a Water Soluble Derivate of Propolis (WSDP). Mellivera 2, 39-46.

POTOČNJAK, D., D. KEZIĆ, M. POPOVIĆ, N. ZDOLEC, H. VALPOTIĆ, V. BENKOVIĆ, G. MRŠIĆ, A. KOVŠCA JANJATOVIĆ, G. LACKOVIĆ, I. VALPOTIĆ (2012): Agerelated changes in porcine humoral and cellular immune parameters. Vet. arhiv 82, 167-181.

PURKINS, L., E. R. LOVE, M. D. EVE, C. L. WOOLDRIDGE, C. COWAN, T. S. SMART, P. J. JOHNSON, W. G. RAPEPORT (2003): The influence of diet upon liver function tests and serum lipids in healthy male volunteers resident in a Phase I unit. Br. J. Clin. Pharmacol. 57, 199-208.

DOI: 10.1046/j.1365-2125.2003.01969.x

RAUW, W. M., O. PORTOLE'S, D. CORELLA, J. SOLER, J. REIXACH, J. TIBAU, J. M. PRAT, I. DIAZ, L. GOMEZ-RAYA (2007): Behaviour influences cholesterol plasma levels in a pig model. Animal 1, 865-871.

DOI: $10.1017 / \mathrm{S} 1751731107000018$

REINWALD, S., C. M. WEAVER (2006): Soy isoflavones and bone health: a double-edged sword? J. Nat. Prod. 69, 450-459.

DOI: $10.1021 / \mathrm{np} 058104 \mathrm{~g}$

ROSOL, T. J., C. C. CAPEN (1999): Calcium-regulating hormones and diseases of abnormal mineral (calcium, phosphorus and magnesium) metabolism. (Kaneko, J. J., J. W. Harvey, M. L. Bruss, Eds.), Harcourt Brace \& Company Asia PTE LTD, Singapore. pp.619-702.

STEPANOVIĆ, S., N. ANTIĆ, I. DAKIĆ, M. ŠVABIĆ-VLAHOVIĆ (2003): In vitro antimicrobial activity of propolis and synergism between propolis and antimicrobial drugs. Microbiol. Res. 158, 353-357.

DOI: 10.1078/0944-5013-00215

ŠPOLJARIĆ, D., G. MRŠIĆ, M. J. PETEK, I. ŠPOLJARIĆ, S. SREČEC, Ž. CVRTILA FLECK, K. ŠPIRANEC, D. MIHELIĆ, L. KOZAČINSKI, M. POPOVIĆ (2013): Chemical evaluation of the quality of meat of broilers fed with the supplement of nature propolis. Meso $15,406-410$.

VALPOTIĆ, H., M. SAMARĐIJA, S. TERZIĆ, S. VINCE, M. ŠPERANDA, G. LACKOVIĆ, B. HABRUN, N. MAS, D. ĐURIČIĆ, P. KOČILA, F. MARKOVIĆ, I. VALPOTIĆ (2016): Effect of mannan oligosaccharide supplementation on blood and intestinal immune cells, bacteria numbers and performance in weaned pigs. Acta Vet. Brno 85, 267-276.

DOI: $10.2754 /$ avb201685030267 
I. Stolić et al.: Effect of native propolis on biochemical parameters in weaned piglets

WERDI PRATIWI, N. M., P. J. MURRAY, D. G. TAYLOR (2006): Total cholesterol concentrations of the muscles in castrated Boer goats. Small Ruminant Res. 64, 77-81.

DOI: $10.1016 /$ j.smallrumres.2005.04.016

ZHENG, W., J. HENGEVOß, S. T. SOUKUP, S.E. KULling, M. XIE, P. DIEL (2017): An isoflavone enriched diet increases skeletal muscle adaptation in response to physical activity in ovariectomized rats. Mol. Nutr. Food Res. 12, 160084-160092.

DOI: $10.1002 / \mathrm{mnfr} .201600843$

Received: 21 September 2017

Accepted: 25 January 2018

\section{STOLIĆ, I., M. POPOVIĆ, G. MRŠIĆ, K. VLAHOVIĆ, D. ŠPOLJARIĆ: Utjecaj prirodnog propolisa na biokemijske parametre u serumu odbijene prasadi. Vet. arhiv 89, 201-210, 2019.}

\section{SAŽETAK}

Svrha ovoga istraživanja bila je odrediti utjecaj prirodnog propolisa na razvoj odbijene prasadi (križanaca između pasmina švedski landras i jorkšir) praćenjem odabranih biokemijskih parametara (ukupni proteini, albumini, ALP, AST, ALT, GGT, glukoza, urea, kolesterol i trigliceridi). Šezdeset prasadi podijeljeno je u dvije skupine. Prasad u kontrolnoj skupini hranjena je standarnom krmnom smjesom za odbijenu prasad (SKS), dok je standardna krmna smjesa prasadi u eksperimentalnoj skupini svakodnevno bila obogaćena propolisom u količini od $1 \mathrm{~g} / \mathrm{kg}$ krmne smjese. Obje su skupine hranjene ad libitum. Hranjenje, smrtnost i biokemijski parametri iz seruma praćeni su periodično. Dodatak propolisa nije znatnije utjecao na konačnu masu, ali je smanjio broj proljeva. U odnosu na kontrolnu, u eksperimentalnoj skupini razina ALP-a, GGT-a, uree, kolesterola i triglicerida porasla je, dok se koncentracija albumina smanjila. Istraživanje je pokazalo da propolisom obogaćena hrana pozitivno djeluje na zdravlje, što može dugoročno omogućiti brži rast zdravijih i težih životinja.

Ključne riječi: prasad; prirodni propolis; rast; izoflavonoidi 